\title{
Understanding Security as a Complex Military Operation: The Boko Haram Terrorism in Northeast Nigeria in Perspective
}

\author{
${ }^{1}$ Imoh Imoh-Itah, ${ }^{2}$ Luke Amadi ${ }^{3}$ Roger Akpan \\ ${ }^{1}$ Department of Public Administration, Akwa Ibom State University, Obio Akpa Campus \\ ${ }^{2,3}$ Deprtment of Political Science and Administrative Studies, University of Port Harcourt, Nigeria
}

\begin{abstract}
This article seeks to explicate the dynamics of security in recent decades as a complex military operation (CMO) including internal and external issues raised by the increasing resurgent Boko Haram terrorism in northeast Nigeria. It argues that divergent terrorist attacks in the global South at the end of the Cold War and in particular at the post 9/11 provide critical need to re-evaluate security as a complex military operation (CMO).The aim is to broaden the scope of security instrumentalities through a multi-stakeholder approach rather than the traditional debates that uphold that the military is the sole purveyor of security. While CMO implies divergent military tasks, the causal connection with security has been rarely studied. As global attention is focused on global terrorist groups such as the Al-Qaeda networks, Al-Shabaab, ISIS etc, devastating internal terrorist attacks such as the ongoing Boko Haram terrorism in northeast Nigeria including suicide bombings, wanton destruction of lives and properties, use of various lethal objects such as explosives resulting in internally displaced persons(IDPs), require urgent policy attention. This article is a content review which derives from human security theoretical framework and secondary data sources notably reports, books, internet materials and bulletins on the ongoing terrorism. The article concludes that failure to re-strategize through effective civil/military relations and multi-dimensional participatory approaches would repeatedly derail terrorist transformation. It made some policy recommendations.
\end{abstract}

Keywords: Security, Complex Military operation, Terrorism, Counter Terrorism, Strategies

\section{INTRODUCTION}

On Tuesday, February 9, 2016 at the Internally Displaced Persons' (IDPs)camp at Dikwa in Borno State, a female teenage suicide bomber developed cold feet to bomb the camp against the instructions of the Boko Haram terrorist sect rather she removed her vest and refused to attack the IDPs which included her father and relatives (AP,2016).This is one among several strategies devised by the Boko Haram terrorist group to unleash terror on the people and defy possible surrender to the federal military.

Boko Haram which means "Western education is evil" is a terrorist group which emerged in the northeast Nigeria in the 2000s. Its alleged objective is to Islamize the northeast Nigeria. Their terrorist strategies have defied counter insurgency efforts of the Nigeria military. These have provided a critical need for a closer look at the complexities of security.

The resurgent change in security dynamics at the intra state level had taken divergent turn since the end of the Cold War. This similarly underscores the need to deepen the study of security as a complex military operation. This is premised on a critical engagement on evaluating the nature of military operations in recent times as a counter terrorist agent.

The study of complex military operation(CMO) is undoubtedly an attribute of recent security threats such as the ongoing terrorism. Although CMO is a recent scholarly agenda, it encompasses organized military engagements involving state, and non-state actors, in reaction to an evolving situation. Such operations are primarily structured within a definite military schedule and aims to arrest emerging sites of problem to the advantage of the state (Wikipaedia,2015). As one of the most rarely employed terms in social discourse, complex military operation(CMO)has in recent decades assumed a central role in a number of military assignments both in the global North and South including strategic and military intelligence research. 
However, despite its use and application, CMO has remained an increasingly elusive phenomenon in research on military tact and intelligentsia in most developing economies. This provides the compelling need to explore this area of research inquiry. CMO encompasses challenging and complicated military response and intervention which might assume warfare or non -warfare feature but in most cases identified with specific code name for national security purposes (Glantz,1991;Wikipaedia,2015). Such military operations as Glantz, (1991) recounts are coordinated features integral to the armed forces for strategic response to military operations at divergent echelons of war.

Recent scholarship and debates suggest that there are a number of debates surrounding security (Ulman,1983;Mathews,1989). The contention has been to move security away from the largely militaristic notion of the concept to a multi-dimensional scope. Realists continue to maintain its narrow conception of security as its "state-centric, militaristic" definition of security emanates from a masculine bias inherent in the theory (Hoggensen \& Rottem, 2004; Alison, 2007; Romaniuk, 2009).

The Copenhagen School of Security Studies (Buzan et al.,1997) is considered the leading study that argued about broadening and deepening the security concept from military and political to societal, economic and environmental security and threats to identity (societal security). This includes a number of territorial and inter-territorial perspectives to security largely at cross national boundaries. Buzan et al., (1997) argue that security is related not only to states and military capabilities, but that security affects all "human collectivities" and is influenced by sectors such as; the political, economic, societal and environmental ones. They define security as "the absence of violence, or use of force".

This increasing debate on security and emergent threats with divergent implications gave rise to the debate on "redefining security"(Ulman,1983;Mathews,1989;UNDP,1994;Klare,1996;Paris,2001).This emerged at the heels of post -Cold War novel security threats specifically at the micro level. It points to the argument that existing security theory lacked emancipatory claims to transform the wider human society, thus pointing to re-conceptualizing military intelligence (Connable,2012).More so are the poor societies of the Third World societies who are largely missing out on prevailing security debates (Dalby,2002).The increasing contention on security debate results in the Third World "security predicament debate". Mohamed Ayoob, (1995) underscores this security predicament and provides seminal insights into the dynamics of individual and institutional security threats of the Third Worldsocieties. He identified lack of "Stateness" and "systemic institutional failure" as partly accounting for insecurity in the Third World. This line of debate is equally reinforced in the contention that describes Africa as a "political refugee"(Mazrui,1995) within the security debates. Ali Mazrui (1995) argues that as a political refugee Africa is confronted with divergent security threats including upheavals arising from political,ethno- cultural, religious, environmental and economic crisis. Much of this is reinforced in Robert Kaplan's "coming anarchy" which reasserts the imminent dangers of corruption, crisis, population explosion and desertification in Africa(Kaplan,1996).

The security challenges of military/civil relationship were also indicated as key in understanding the inadequacy of the militaristic notion of security. Gentry(2004)argues that the military aspects of such complex national endeavors have been identified to be, somewhat inadequate, especially in salvaging low-intensity conflicts other than wars. He argued that such operations have significant civil-military relations.

The intense controversy swirling around $\mathrm{CMO}$ as recent security studies suggest compels changes in military tact and strategy reflected in the resurgent debate on a paradigm shift as Ben Connable (2012) argues. The present research is in line with this argument. This article argues that there is critical need for not only a change in the military/security tact but also a new military capacity building on approach to security and terrorism. The central argument of this article is novel military strategy. Although the complexity of security challenges in Nigeria is discernible as could be seen in the ongoing Boko Haram terrorism, the article contends that greater efforts should be made to deploy requisite tact and strategy within the code of military operation built on multi- dimensional approaches. The article is not suggesting a singular perspective on security that scholars, government and policy makers should adhere to, rather, it proposes an inclusive approach. It argues that a non grounded understanding and use of security both as a concept and social activity is detrimental to theorizing in CMO and undermines effective critical thinking because security is broad and requires multi-dimensional approach. A deconstruction of the existing notion and discourse of security and $\mathrm{CMO}$ is important as the article provides some strategic recommendations for a novel intervention. 


\section{THEORETICAL FRAMEWORK}

Since the 1980s "redefining security" has been a central concern in security studies (Ullman,1983; Mathews, 1989; UNDP,1994;Klare 1996; Paris,2001;Ogata and Sen,2003). This contention has become germane at the neo liberal order as security threats persist. This paper contributes to a new theoretical research inquiry which aims at deepening security studies and threats posed by Boko Haram terrorism. It builds on the human security debate which has since the 1990s proven to be the most influential framework to explore security at the micro level. The Human Development Report,(1994), provides one of the most seminal articulations of human security. It argues that although nuclear explosions devastated Nagasaki and Hiroshima, human-kind has survived its first critical test of preventing worldwide nuclear. But five decades later, that humanity needs another profound transition in thinking-from nuclear security to human security (UNDP, 1994).

This theoretical framework is suitable as it provides key liniments to examine Boko Haram terrorism and security debates. Kofi $\operatorname{Annan}(2000,2005)$ opines that the need for a more human-centered approach to security is reinforced by the continuing dangers that weapons of mass destruction, most notably nuclear weapons, pose to humanity: their very name reveals their scope and their intended objective, if they were ever used. He further states that Human security, in its broadest sense, embraces far more than the absence of violent conflict. It encompasses human rights, good governance, access to education and health care and ensuring that each individual has opportunities and choices to fulfill his or her potential.

Human Security as explicated, is understood within its four pillars: freedom from fear, from want, from hazard impacts and to live in dignity within a state of law (Dalby et al., 2009). The UNDP Human Development Report (HDR) further advanced the argument on "redefining security" from a human dimension. The report shows that humanity requires a substantially new manner of thinking if mankind is to survive.

The human security conceptual framework is suitable to examine the complex security challenges in the northeast Nigeria including the forced migration, rape,abduction, internally displaced persons(IDPs),hunger and food security issues and the increasing problems of fear and threats of restriction from movement .This reinforces debates on protecting people from critical situations of threat.

Ogata and Sen (2003) argue thathuman security means protecting people from critical and pervasive threats and situations. It means creating political, social, environmental, economic, cultural and public safety systems that together give people the building blocks for survival, livelihood and dignity in their hopes for a better quality of life. The twin goals of "peace and development" probably describe best mankind's immediate as well as long-term aspirations, human security is concerned with safeguarding and expanding people's vital freedoms. It partakes both of protecting people from critical and pervasive threats and of empowering them to take charge of their own lives. Protection refers to the norms, policies and institutions that are essential for shielding people and require governments to exercise top-down vigilance, especially in ensuring the rule of law and democratic governance (Sen,1999).

Similarly, Annan,(2000:1) corroborates this freedom encompassing "freedom from want, freedom from fear, and the freedom of future generations to inherit a healthy natural environment -- these are the interrelated building blocks of human - and therefore national - security".

Thus, in providing a theoretical connection between human security and terrorism, the paper advances the argument that human security is critical to human survival.The aim is to inject novel theoretical trajectory in security challenges that particularly affect the most vulnerable groups namely women ,children and the girl child and essentially deepen the debates on terrorism ,complex military operation(CMO)and security which are currently affecting peaceful existence of the north east and Nigeria in general. The notion of rearticulating the more effective strategic approach to counter the insurgent activities is both expedient and critical these are some of the fundamental objectives of this study in deploying the human security theoretical framework.

Against this theoretical background, the study deploys the local level of analysis, with emphasis on the insurgent group in the northeast. This is informed with the increasing killings, threats and 
destabilization of the region by the sect. This would be linked to a wider conceptual elucidation of the research question which seeks to analyze security as a complex military operation specifically in relation to the ongoing sect and proffer alternative counter terrorist strategy.

\section{Security as a COMPlex Military Operation in Nigeria}

Nigeria is a multi -ethnic society. The sociologist, Onigu Otite, has provided an authoritative list of 374 ethnic groups (Otite, 1990).According to the World Bank(2014),Nigeria has a land Area (SQ. $\mathrm{KM}$ )measured at 910770 . Land area includes a country's total area, excluding area under inland water bodies. Nigeria has a population of about 178.5 million people in 2014 (BoS,2014).It is the largest and most populous country in Africa.

Security has been one of the major threats to human lives and property in Nigeria (Amadi and Ogonor,2015). Insecurity in Nigeria takes various dimensions including environmental insecurity such as the Niger Delta and oil induced environmental degradation, ethno-religious insecurity and threats such as the Christian and Muslim clashes,ethnic identity agitation such as the Afenifere,Arewa consultative forum, Oha na Eze ndigbo. Ijaw National Congress(INC),Ethnic militia groups such as the defunct Niger Delta Peoples Volunteer Force(NDPVF),Movement for the Emancipation of the Niger Delta (MEND),Niger Delta Vigilante(NDV),Indigenous Peoples of Biafra,(IPOB) and postcivil war clamor for self-determination, the Shiite sectarian killings, rural violence and banditry such as the Fulani cattle rustling in northern Nigeria etc,all pose security threats to the Nigerian citizenry.

To consign these threats to the military alone reinforces the complexity of security. The Nigerian Army (NA) is the land branch of the Nigerian Armed Forces and the largest among the armed forces. Its major formations include the 1st Division, the 2nd Division, the 3rd Armored Division, 81st Division, 82nd Division, and recently formed 7th Division (wiki,2015).This article is concerned with the land army and not the entire armed forces.

The conceptual debates linking security and complex military operation emphasizes the increasing challenges faced by the military to ensure security. In the particular case of the Boko Haram, the security threats perhaps have been enormous. Several studies have examined security to describe mixed theories and studies such as the environment, gender, food, human security (UNDP, 1994; ILO, 1974; Dalby, 2001; Oswald, 2008).However, sustained treatments that theorize security and CMO have been scant.

There have equally been scant studies identifying casual connections between security scholarship and CMO, although one can find a few debates based on CMO (United Nations, 2003; Guttieri, etal; 2014). Nevertheless, regular discussions of CMO (Gentry, 2000) suggest the importance of military in security studies. This underscores the relevance of studying security and CMO binary. Although debates on redefining security argues on broadening and widening the scope of security studies beyond military our debate does not run counter to that debate rather this article strengthens the debate on broadening the scope of security studies through a multi-dimensional strategy.

In Nigeria there are a number of threats posed by issues such as terrorism to humanity. A merely descriptive use of security creates complex binaries that may not provide requisite theoretical edge in recent global security challenges and dynamics. Thus, a conceptual exploration of both terms to Provide a broader understanding of the enormous challenges posed by security to wider human society is sought.

There are divergent debates on security as a product of global and local interaction,(Buzan,etal,1997; Dalby,2002).The contention is that security needs to be understood as a complex and dynamic trend constituted by, socio-political, environmental and economic components.

Understanding security as a complex military operation (CMO)reinforces the fact that CMO relations are also divergent. Essentially inability to understand these complexities in both concepts could blur a fuller comprehension of the problems posed by security as well as the threat security might pose within the wider development context. Socially, a critical security theory considers security as an interaction on threats to humanity with differential implications. Complex Military Operations (CMO)challenges and recognizes the importance of specific leadership, strategic, critical and salient matters that call for policy discourse.

Debates on CMO have featured in scholarship critical of strategic military operations as an global security shift. Complex operations debates centers on interrelated security interpretations. Notions towards this perspective for instance include the evidence replicated in the Army Field Manual 3- 
24/Marine Corps Warfare Publication 3-33.5, which provide an outline of interrelated military operations.

Most of the central panacea to terrorism in relation with CMO is counter terrorism or counter insurgency. Counter insurgency provides a complex whole in military dynamics which recommends exploring the entire environment through three distinct perspectives : the population, the enemy, and the host nation(Connable,2012). To explore CMO it is expedient to understand the concept of complex environment. Complex environments are those locations riddled with ambiguities that defy military penetration. A particular complex environment in the present parlance is the north East Nigeria currently occupied and controlled by the Boko Haram terrorists.

It is perhaps expedient to posit that security and CMO are not mutually exclusive. Essentially, if security consists of only threats to human life, it requires a critical theorizing and articulation within strategic theory and practice. In this article, we are primarily concerned with the theoretical and practical strands of $\mathrm{CMO}$ and security that seeks to advance the course of military /security relationship beyond the regimented military operation. Thus an all-inclusive paradigm involving novel civil-military relationship is suggested to integrate a wider segment of the society including the NGOs, non-State actors and similar civil society groups.

This inclusive dynamic has been reflective of the criticisms against CMO which ranges from uncertainty, contradictions and logisctics.in the particular case of Boko Haram logistic remained a key challenge which in the cause of the operation rendered most military officers vulnerable to the book haram sect. The trial of the former Chief Security Officer(SCO) to former President Jonathan Col. Sambo Dasuki on diversion of funds to procure arms to attack the insurgent group is evident.

Connable,(2012) recounts that these key issues including the caliber of personnel and commitment to national security cause are critical and have some validity in contemporary military intelligence debate.

Thus there is need to re-examine the issues surrounding CMO such as the growing tension, deceit and contradiction in arresting the Boko haram terrorist group. This has made the understanding of CMO often an uncritical sphere of study which furthers security threats to humanity. Such security threats occur frequently and are often reported in mainstream media including debates which invite logical engagement. This increasingly informed the need to revisit security and CMO within the remit of military strategic intelligence the subsequent section discusses dynamics of terrorism and CMO it opens with brief literature review on security and CMO and provide key missing links in the concepts. The analysis concludes with an exploration of security and the increasing challenges it poses to CMO with alternative dimensions.

\section{DIMENSIONS OF THE BOKO HARAM TERRORISM}

Since the beginning of 2014, the northeast has witnessed an increase in violence, this has been a major humanitarian crisis that has taken several dimensions including bombings, burning down of houses, use of fireworks and explosives and abduction. The International Organization for Migration reports that the number of people in northeast Nigeria displaced by Boko Haram's six-year insurgency rocketed to more than 2.1 million -- or 300,000 households (Winsor,2015).

The following sections is devoted to the underlying dimensions of Boko Haram terrorism.Perhaps Nigeria has been living on a false security paradigm(McNamara,1990) This results in the increasing security challenges encompassing food insecurity, human security, kidnapping, militancy, environmental security, population ,gender ,religious, political, ethnic crisis, Boko Haram terrorism which pose threats to the Nigerian State .There seem to have been a poor grasp of the latent and manifest implications of these security threats. McNamara (1990:17) argues that for any society to overcome the sense of false sense of security and achieve adequate security, the society must deal with problems of food shortage, population explosion, improve its productivity level, per capita income, technological development, improvement on public utilities and unemployment(adopt strategies for religious tolerance and criminal politicking).

The scholarship on terrorism suggests controversy in clearly defining and understanding what constitutes terrorism in security studies. The difficulty includes the absence of understanding when the use of violence is legitimate or not. For instance when the state or the military deploy violent 
means to achieve its aim how could that be classified in contrast distinction with when individuals or groups deploy similar illegitimate violent means to achieve their objectives. This absence of a common standard to measure and determine what constitutes terrorism has increasingly resulted in contention and increasing debates on conceptual understanding of the term terrorism. This notwithstanding terrorism has been conceptualized from divergent perspectives and schools of thought.

The term terrorism in modern security studies is both criminal and derogatory and denotes a situation of absence of morality and legality. Several institutions, scholars and agencies have attempted to conceptualize terrorism. There debates which argue that terrorism include criminal actis involving groups or individual aimed to incite terror in a state which could take various forms often informed by ideological, racial, ethnic, religious or similar inclination. The aim is to invoke political attention for whatever objectives or gains by the terrorists(UN,General Resolution,1994).

Terrorism has become one of the most widely employed and disputed terms in contemporary democracy. In the developing democracies of Africa Asia and Latin America terrorism had emerged as central to the understanding of recent trends in global security studies (Cornable,2012). The European Union Framework Decision on Combating Terrorism (2002) argued that terrorist offences are certain criminal offences against persons and property which results in serious damage on a country or an international organization, intimidating a population; or unduly compelling a Government or international organization to perform or abstain from performing any act; or seriously destabilizing or destroying the fundamental political, constitutional, economic or social structures of a country or an international organization.

Terrorism has attracted a wide range of scholarly and research attention. While some see terrorism as criminal offences (EU,2002), others have seen it as a site of democratic struggle and resistance against Western hegemony (Lévesque,2015 ), Terrorism have also been critically attacked as an invention of the Muslim fundamentalists to further global religious fundamentalism complicit with terrorist attacks and suicide bombings bestride with jihad fanatics and similar ethno religious affinity. For instance, the Boko Haram sect is opposed to Western education and struggles to Islamize northeastern Nigeria.

The diverse scholarship on the concept of terrorism partly accounts for its contradictory and elusive invention and practice.. This is of the growing debate to unravel the key triggers of global terrorism which seem to defy contemporary policy discourse.

Terrorism as argued by the International Terrorism and Security Research (ITSR) is not new.

Perspectives of the ITSR (2015) is insightful as they contend that terrorism has been described variously both as a tactic and strategy; a crime and a holy duty; a justified reaction to oppression and an inexcusable abomination. The carnage implicit in the Boko Haram activities in Nigeria deserves an exhaustive discourse on terrorism and $\mathrm{CMO}$ particularly in the context of counter terrorism challenges.

UN Security Council Resolution 1566 (2004)argues that terrorism is a criminal act, against civilians, aimed to cause death or serious bodily injury, or taking of hostages, with the purpose to provoke a state of terror in the general public or in a group of persons or particular persons, intimidate a population or compel a government or an international organization to do or to abstain from doing any act.

As a criminal act the strategy of terrorists is to commit acts of violence that draws the attention of the local populace, the government, and the world to their cause (ITSR,2015).A key issue involved in terrorist attack is the need to attract publicity, and to often claim responsibility for terrorist attacks selecting key targets that stand in opposition to their cause. The efficacy of "the terrorist act lies not in the act itself, but in the public's or government's reaction to the act"(ITSR ,2015;1)For instance the October 1st 2014 Bombing of the Eagle Square by Movement for the Emancipation of the Niger Delta People (MEND).

The countless number of dead bodies and millions of internally displaced persons(IDPs)are critical dimensions of the Boko Haram terrorist attacks. Most incendiary include sectarian bombings and killings and internally displaced persons(IDPs)in Northeast Nigeria which have taken divergent forms such that this article may not exhaustively capture. Some of them include the sectarian violence in Jos (2004, 2010, and 2011). Serial bombings, abduction and killings in Maiduguri (since 2004 to date). The December 31st 2010 Bombing of Mogadishu Military Cantonment Mammy Market Abuja 
(Omole,2013). The May 29, 2010 bombing at the Presidential Inauguration in Abuja. The October 1st 2010 bombing in Abuja that disorganized the marking of Nigeria's 50th Independence Anniversary. The Mammy Market bombings in Bauchi, and Zuba near Abuja in 2011 (Omole,2013). Post-April 2011 Presidential Election violence in the Northern parts of Nigeria. April 8,2011 Suleja INEC office bombing. May 29, 2011 bombing of social drinkingsports in Maiduguri and Zuba an outskirts of Abuja (Omole,2013) The June 16,2011 bombing of the Nigeria Police Force Headquarters in Abuja , August 26, 2011bombing of UN House in Abuja. Nov 4, 2011 bombing of Army Task ForceOperational, Police Headquarters and other government buildings in Damaturu, Yobe State and Maiduguri in Borno State. Christmas day bombing at St Theresa Catholic Church in Madalla near Abuja (25 December2011).Mubi, Yola, Gombe and Maiduguri bombings (5-6 January 2012).Kano bombings (20 January and 1 February 2012). HQ 1 Division Nigerian Army and Kawo bridge bombings in Kaduna (7 February 2012) (Omole,2013).The October 2015 Nyanya and Mararaba suicide bombings in Abuja among several others.

Despite this increasing terrorist attacks and clamor for support by the international community particularly the United States, contrary views in the international circle on the real supporters of the faceless-terrorist group abound. For instance Levesque(2015)argues whether "Boko Haram is a CIA Covert Up to Divide and Conquer Africa", equally, Bowie,(2012)made similar observation which he termed "Fertile Ground for US Sponsored Balkanization".

Mark P. Fancher (2015)similarly critiques the hypocrisy and the imperialist arrogance of Western countries, declaring their willingness to expand and establish their military presence in Africa.

These rekindle novel critical thought on the real motives and key actors in the Boko Haram terrorism which further underscores the failure of Nigeria's military leadership to evolve critical thinking and requisite intelligence. Although Nigerian military, is largely conceived as integral to power, which takes on a more prominent role as the army participates in security and peacebuilding including aspects of a joint organization primarily charged with such responsibilities, similar agencies such as NGOs, para military organizations, often engage in similar activities. This has increasingly resulted to the debates on improved civil/military relationship as strategy to counter terrorism. Having been explored in recent development and policy studies, security has become an important area of study to understand a number of issues that constitute threats to freedom including terrorism which in recent times is a re- occurring threat in most societies in the South notably the Middle East and Africa. This understanding of security as a complex military operation (CMO) reinforces the failures of the military to strategically evolve an effective counter terrorist movement or strategy to douse the imposing insecurity of terrorist attacks. This has received recent attention among opposing perspectives whose contrary views are mainly as a result of strong divergences on the meaning and implications of complex military operation. What constitute specific complex military operations remains ambiguous in effect, riddled in paradoxes. In its contradictory images and possible rearticulation. CMO becomes an indistinct concept adopted without rigorous theoretical grounding.

\section{Multi-Dimensional Approach to Counter Terrorism}

There are a number of literatures within the context of commemoration or critique of every social phenomenon. The term complex military operation has received such divergent contention-.Gentry (2004)identify such complexities as he contends that, military operation are premised on the objective of deploying strategies to directly accommodate the local civilians, the civil institutions and government institutions.

In development studies, complex military operations have had such scant attention. It is only recently that the term complex military operation (CMO) has gained visibility in military and security studies in Nigeria perhaps as the persistent Boko Haram insurgency calls for novel critical thinking. Importantly in 2015 the Nigerian Defense Academy called for papers on Complex Military Operation. Despite this novel awareness, there are scant studies specifically interrogating security as a complex military operation and in particular exploring dynamics of contemporary military/civil relationship in the ongoing post Boko Haram terrorism in the northeast Nigeria.

Although modern military is a colonial legacy with motives linked to power and control mechanisms that foster some nationalism, since military power was a way to promote a nation's goals, internal contradictions in the Nigerian military since the mid -1960s down to the end of the civil war in 1970 
largely vitiate its claim to a national look. This increasingly affects patriotism and genuine commitment to national military ethos as military coups and counter military coups became the order of the day in the mid-1960s.

Significantly, security/military operations are strategically planned to fit a wide range of situations including social, political, environmental, economic, cultural etc. Such operations could involve conflicts, peace building, or wartime issues. It often requires critical thinking and strategies. Failure to adopt requisite strategies for specific operations makes the actualization of such operations difficult and complex.

On the other hand, the use of proven tactics, techniques and procedures, commonly referred to as TTPs,(Connable,2012)often proves effective and simplifies complex operations. Thus themes such as security requires urgent policy and strategic policy attention.

Terrorism is explored either as state terrorism or group / individual terrorism. The underlying assumptions of terrorism include; violence, fear, intimidation, threats, killing and achievement of stated objectives. It is the premeditated adoption of violence or force designed to instill fear. Terrorism by individuals or groups is meant to coerce or intimidate governments, its agencies or institutions in pursuit of stipulated goals by the group. While terrorism by the state is meant to intimidate, oppress or subjugate the citizens in the interest of holders of political power often through the blatant use of force.

In most military dictators there are incidence of state terrorism such as the killings in Ogoni in the Niger Delta by the Abacha military administration in the 1990s, in Nigeria. Equally under the democratic governments especially in developing democracies such as Nigeria, there have been evidence of extra judicial killings such as Odi massacre in the present Bayelsa State in the Niger Delta, and Katsina Ala and Vandakia in Benue State all during the Obasanjo administration and the Gbaramatu killings in Delta State by the Military Joint Task Force(JTF)during the Yar'Aduah administration in Nigeria.

Military strategists are meant to mold each operation to meet the challenges of each enemy situation. EvaTalent (2000) identified four types of military operations: offensive, defensive, stability and support. There are a number of military operations which serve different purposes some could be used for peace building, or counter insurgency and terrorism, some are deployed in the battlefield by commanders to handle different military engagements including enemy attacks and battle field combats. Such complex military operations(CMO)as outlined in manuals such as Army Field Manual 3-0, "Operations," ,identified some military operations deployed in recent times by soldiers. Such as offensive, defensive, stability and support operations.

Offensive operations are mainly used during times of war primarily to change the course of events to the favor of the offended it includes violence and force. It can also be used to deter future conflicts. For example, declaring a state of emergency in Maiduguri northeast Nigeria to check insurgency activities strategically aims to check future security threats.

Defensive operations are designed to prevent military casualties in the battle while setting the stage for a future offensive operation(Talent,2000). During a defensive operation, military forces protect themselves, their area of operations (commonly called the AO) (Talent,2000). Stability operations hold military situations together during tenuous times. Stability operations occur before and after periods of active combat. Building community facilities, responding to local crises and training local law enforcement officers are examples of stability operations (Talent,2000). Support operations provide reinforcement to local authorities, both foreign and domestic, during times of need. This type of operation can be used concurrently with a stability operation and during defensive operations. Support operations are designed to win wars, resolve conflict and promote peace. Support operations can also include responding to national emergencies and disasters (Talent,2000).

Contemporary counter insurgency strategies call for multidimensional coordinated approach specifically designed for varying assignment and situations. Robert Cassidy(2004) contends that effective engagement in the contemporary security landscape, requires a novel mindset that must be deployed with emphasis on stability operations and counter-insurgency. To build a collective consensus on the term terrorism is important to provide effective counter terrorist strategy. This has been a handicap. A novel global anti- terrorist convention is critical to device binding principles to 
address global terrorism. Such conventions would redefine terrorism to accommodate state specific and global practices which clearly delineate what is termed terrorism and what is not terrorism.

Having explored the ongoing trends in terrorism in Nigeria, novel paradigms to counter terrorism which are increasingly emerging is expedient. In the US army, Connable (2012) proposes a new paradigm namely Behavioral Intelligence Analysis (BIA)-He contends that analysts adopting BIA would check the channelization of actors. Red,- white,- and green- would disappear from the operational and analytic lexicon(Connable,2012:17). He argues that a unified approach is suitable "rather than sharing analysis between meat eaters- and leaf eaters,- all analysts would be omnivores"

Combating terrorism involves a multi -dimensional approach which include all stake holders from a bottom top approach. It is not an exclusive military affair, rather an all-inclusive military/civil relations approach. It encompasses defensive (antiterrorism/anti-insurgency action) and offensive (counterterrorism) actions.

The strategy embedded in antiterrorism encompasses all measures by component military units and individuals take to mitigate the possibility being contained as victim to a terrorist act. Antiterrorist act involve defensive strategies that ameliorate the vulnerability of humans and non- humans such as property. There are often variations in counter terrorist strategies based on the magnitude of the threats(Connable,2012).

On its part, counter terrorism includes the full range of offensive measures to prevent, deter, and respond to terrorism. It encompasses a number of measures, local measures include only those actions taken to terminate an incident or apprehend individuals responsible for terrorist acts. Other countermeasures--preemption, intervention, or retaliation with specialized forces operating under the direction of the NCA--have the characteristics of attacks or raids(Connable,2012). Much of the Nigerian military strategies have been fraught with lack of critical thinking. Early establishment of critical thinking is important for successful military operations. This include interface with the local communities or non-military component, tactical intelligence flow, management and sourcing of intelligent information and communications between all stake holders to provide the critical intelligence that Nigeria military forces require to establish a strong hold on the terrorists

Operational intelligence must support the targeting effort of operational-level fires and/or set the stage for operational-level maneuver(Connable,2012). In conflict and terrorist attacks such intelligence might follow the processes adopted for a conventional battlefield or a modified process that focuses on non-military information. Civilian trends are often as important as operational information.

There is usually need for templates and guidelines for the entire rank and file. Military intelligence personnel must be equipped with up to date and regular intelligent information.

The foundations of a multi -dimensional approach of counter terrorism has been important as it is both participatory, inclusive and bottom top, because the growing dominant studies on terrorism have not provided a collective consensus on what and how to understand terrorism, a central contention is that it is a criminal act, violent and pre meditated. In particular by a group and targeted on another group to instill fear and meet the objectives of the terrorists.

\section{Conclusion}

Security remains central in contemporary development agenda and will perhaps remain topical in the near future both in the global North and South. As new security threats emerge, the inevitability of strategies to counter same remains critical. This is part of the thesis of this article in exploring security as a complex operation.

Against this back drop and as this article demonstrates, the complexities of security goes beyond the military. It is essential for all stakeholders in anti- terrorism and security networking to collaborate and contribute meaningfully to security and counter terrorism such as the particular case of Boko Haram insurgency.

The primary objective of this article was to provide some useful insights in understanding the complexities of security in which all stakeholders should play active part to strengthen irrespective of varying contexts. The foregoing suggests that the concept of security has been complex and often deployed to explore a number of theoretical explorations and debates. This challenges any claims to a 
universalistic theory of security, which would blur the fuller comprehension of the concept. In relation with the issue of terrorism, the study has established the persistent challenges associated with counter terrorist strategies of the Nigerian military. It suggests a deployment of multi-dimensional approach involving all stake holders.

The article has attempted to explore the ongoing issues associated with security from its understanding as a complex military operation. Both concepts were deployed in an explicitly political sense as it particularly applies to human security in terms of freedom from fear, anxiety, movement etc. Whereas the article argued beyond the notion of security from an explicit military perspective, it makes a novel contribution which argues for a multi stakeholder approach to anti insurgency and anti -terrorism. This is aimed at a collaborative effort at approaching the perennial problems of terrorism in the northeast Nigeria. Such suggested strategy should involve both civil society groups, men, women, youth and children.

The notion for a civil/military collaboration is to represent the individual and the territory they inhabit .In other words, civil-military security strategy is conceptualized in relation to counter threats on the individuals and the military, thus it is a collective anti- vulnerability strategy -both internally and externally to understand and counter the threats -that have the potential to upturn the military. Although it has been very difficult to effectively win the war on Boko Haram terrorism, a number of internal dynamics such as informants to the sec and saboteurs have been critical and indeed provides a need for an integration of the non- military component in the war against terrorism. Similar evidence such as the diversion of the funds for procurement of arms by the top government officials are instructive, this opens to future research.

\section{REFERENCES}

Alison, M. (2007)."Wartime Sexual Violence: Women's Human Rights and Questions of Masculinity." Review of International Studies, No. 33 pp.75-90.

Annan.K "Report of the Secretary-General on the Work of the Organization". General Assembly Official Records Fifty-fifth session Supplement No.1 (A/55/1). New York: United Nations, 2000, p.4.

Annan K (2005). "Towards Development, Security and Human Rights for All". Available www.ohchr.org/Documents/Publications/A.59.2005.Add.3.pdf [Accessed 10/7/2014]

Ayoob,M (1995). The third world security predicament: State making, regional conflict and the international system. London: Lynne Rienner Publishers.

BuzanB,WaeverO, wilde J( 1999).Security a New Framework for Analysis. Lynne Rienner Publishers

Cassidy,R (2004). "Back to the Street without Joy: Counterinsurgency Lessons from Vietnam and Other Small Wars, Parameters, US Army War College Quarterly pp: 74.

ConnableB(2012).Military Intelligence Fusion for Complex Operations A New Paradigm occasional Papers. National Defense Research Institute pp.1-28.

Dalby, S (2002).Security and Ecology in the Age of Globalization ECSP Report · Issue 8, 95: 95 108.

Dalby S, Brauch H, Oswald U (eds),(2009). Environmental Security Concepts Revisited During the first Three Phases(1983-2006) in Facing Global Environmental Change: Environmental, Human, Energy,Food,Health and Water security Concepts. Berlin Heidelberg-New

York: Springer-Verlag pp1520.

EU(2002).The European Union Framework Decision on Combating Terrorism.Oxford Press.

Fancher, M (2015)."Arrogant Western Military Coordination and the New/Old Threat to Africa", Black Agenda Report, 4 February.

Gentry J(200) .Complex Civil-Military Operations A U.S. Military-centric Perspective. Naval War College Review, Autumn 2000, Vol LIII, No. 4.

Guttieri K, Franke Vand Civic M(eds.).(2014).Understanding Complex Military Operations: A Case Study Approach. New York: Routledge.

Glantz, D. (1991).Soviet Military Operational Art: In Pursuit of Deep Battle. London: Frank Cass What is Terrorism? Available at http://www.terrorism-research.com.

Hoogensen G, and Rottem,S (2004)."Gender Identity and the Subject of Security."Security Dialogue, Vol. 35, No. 155-171. 
Klare ,M. (1996). "Redefining Security: The New Global Schisms". Current History, November.

Lévesque J (2015)Is Boko Haram a CIA Covert Op to Divide and Conquer Africa? Global Research, February 14, Available at http://www.globalresearch.ca/is-boko-haram-a ciacovert-op-to-divideand-conquer-africa/5431177

Mathews, J (1989). Redefining Security , Foreign Affairs, 68:2 p.162

Mazuri A (1995). African State as a Political Refugee :In David Smock and Chester crocker,eds; African Conflict resolution:The US Role in Peacemaking WashigtonDc:United States Institute of Peace Press.

Ogata, S and Sen,A (2003). Human Security Now: Commission on Human Security, Final Report, New York: United Nations.

Otite, O (1990). Ethnic Pluralism and Ethnicity in Nigeria. Ibadan: Shaneson.

OmaleD(2013). Terrorism and Counter Terrorism in Nigeria: Theoretical Paradigms and Lessons for Public Policy. Canadian Social Science, 9 (3), 96-103. Available from: http://www. cscanada.net/index.php/css/article/view/j.css.1923669720130903.2916 DOI: http://dx.doi.org/10.3968/j.css.1923669720130903.2916

Paris,R(2001).Human Security: Paradigm Shift or Hot Air? International Security no 2.26: 87102.

Romaniuk,S (2009). "Engaging Gender (In) Security Gender Links".Available http://www.Genderlinks.org.za/article/engaging-gender-in-security-2010-01 05,(Accessed April 4,2016)

Sen, A (1999). Development as Freedom, Oxford Press Talent E(2000)."What Are the Four Different Types of Military Operations"? http://www.ehow.com/info_8113615_four-different-typesmilitary-operations.html

UNDP Human Development Report (1994). "Redefining Security: Human Dimensions”. Oxford University Press.

United Nations, Traditional Peacekeeping's Transformation Into More Robust, Complex Operations Focus of Discussion of Fourth Committee, GA/SPD/267 (17 October 2003), available at www.u n.org/News/Press/docs/2003/gaspd267.doc.htm.

Wikipaedia, (2015). Military operation. Available at www.https://en.wikipedia.org/wiki/ Military operation

Winsor M (2015)."Number of Nigerians Displaced by Boko Haram Increases To 2.1 Million, International Organization For Migration Says "Available at http://www.ibtimes.com /number-nigerians-displaced-boko-haram-increases-21-million international-organization-20837 97 